\title{
ASSESSMENT OF HEAVY METAL POLLUTION IN SURFACE MUDDY SEDIMENTS OF LAKE BURULLUS, SOUTHEASTERN MEDITERRANEAN, EGYPT
}

\author{
Ahmed EI Nemr \\ Environmental Dept. National Institute of Oceanography and \\ Fisheries, Alexandria, Egypt
}

Keywords: heavy metals, sediment, labile, dermal contact, pollution, Lake Burullus, Egypt

\begin{abstract}
I he concentrations of certain heavy metals $(\mathrm{Cd}, \mathrm{Co}, \mathrm{Cr}, \mathrm{Cu}, \mathrm{Fe}$, $\mathrm{Mn}, \mathrm{Ni}, \mathrm{Pd}$ and $\mathrm{Zn}$ ) in the total and labile fractions of muddy sediment samples collected from eleven sites in Lake Burullus in January 2003 were investigated in order to evaluate the pollution status of the Lake. The metal contents were determined by means of Atomic Absorption Spectrophotometer (AAS) using MESS-2 certified reference material (National Research Council of Canada). The average concentrations of the heavy metals analyzed in total sediment fractions exhibited the following decreasing order: $\mathrm{Fe}>\mathrm{Mn}$ $>\mathrm{Cu}>\mathrm{Ni}>\mathrm{Zn}>\mathrm{Cr}>\mathrm{Pb}>\mathrm{Co}>\mathrm{Cd}$, while the average concentrations of the heavy metals analyzed in the labile fraction followed the order: $\mathrm{Fe}>\mathrm{Mn}>\mathrm{Cu}>\mathrm{Ni}>\mathrm{Pb}>\mathrm{Zn}>\mathrm{Co}>\mathrm{Cr}>\mathrm{Cd}$. The concentrations of all studied heavy metals ranged between the Effect Range-Low (ERL) and the Effect Range-Median (ERM) for most studied locations. Metal pollution index (MPI) shows very high values for both total and labile fractions at all the examined locations. Field observation reveals that Lake Burullus received industrial, agricultural and domestic sewage, suggesting that anthropogenic input is the main source of heavy metal contamination. Health hazard calculations for the contaminated sediments exhibited a possibility, of health risk due to long-term exposure of the human to the polluted sediments of Lake Burullus.
\end{abstract}

\section{INTRODUCTION}

Lake Burullus is a coastal lagoon situated along the Mediterranean Sea, between the western Rosetta and the eastern Damietta branches of the River Nile. The Lake is shallow and its 
average depth ranges from 0.5 to 2.1 meter. Seven drains are connected to Lake Burullus (El-Burullus drain, El-Gharbia drain, Nasser Drain, Drains 7,8,9 and 11) which are leading to daily input of pollutants to the Lake Burullus (Fig. 1).

Heavy metals are of the serious pollutants in natural environment due to their toxicity, persistence and bioaccumulation problems. The impact of anthropogenic perturbation is most strongly felt by estuarine and coastal environments adjacent to urban areas. Heavy metals from incoming drains, tidal and fresh water sources are rapidly removed from water body and deposited onto the sediments. Naturally occurring heavy metals usually originate from weathering of rock substrates and reach costal areas through rivers in the form of particulate material. These metals are mainly chemically bound to aluminosilicates, which are not readily bioavailable. However, metals of anthropogenic origin are more loosely bound in sediments and thus are more readily available to organisms (Schropp and Windrom, 1988). Analysis of the labile (leachable) metal fraction of the sediment may be more useful, in terms of discovering its biological significance and the new inputs, than analysis of the total metal fraction (Lacerda et al., 1992; Puente et al., 1996). However, sediment analysis is more indicative rather than water analysis for evaluating the degree of contamination in the aquatic medium due to the stable image over time for the sediment compared with the huge temporal variability in levels of contaminants in water. Furthermore, concentrations of toxic elements are usually higher in sediments with less possibility of contamination of samples during handling and processing, and the analytical methods are simpler.

Heavy metals such as cadmium, mercury, lead, copper and zinc are regarded as serious pollutants of aquatic ecosystems because of their environmental persistence, toxicity and ability to be incorporated into food chains (Förstner and Wittman, 1983). In Lake Burullus, industrial, agricultural and domestic wastes discharges have increased the levels of heavy metals in the lake.

The aim of this study was to investigate the degree of heavy metals pollution and the health hazard due to exposure to the contaminated sediments of Lake Burullus.

\section{MATERIALS AND METHODS}

Selection of sampling stations for sediment sampling from Lake Burullus included the outlets of canal, streams, and drains from 


\section{ASSESSMENT OF HEAVY METAL POLLUTION IN SURFACE MUDDY SEDIMENTS OF LAKE BURULLUS,}

industrial areas into the lake. Surface sediment $(<4 \mathrm{~cm})$ samples were collected from 11 sampling sites (Fig. 1) in January 2003. Surface layer is usually permanently oxidized and thus acts as a barrier to metals that migrate from deeper, reduced areas towards the surface and are retained by iron and manganese oxides. The surface layer of sediments controls the exchange of metals between sediments and water and constitutes a reserve of metals to which benthic organisms are exposed. Samples were transferred into labeled polyethylene bags and stored in the laboratory at $-20^{\circ} \mathrm{C}$ until analysis.

Sediment samples (100\% Mud) were dried in an oven at 105 ${ }^{\circ} \mathrm{C}$ to constant weight $(72 \mathrm{~h}$ ), then ground and sieved. For total heavy metals analysis, $0.2 \pm 0.02 \mathrm{~g}$ duplicate subsamples were weighed into digestion Teflon bombs and a $3: 1$ mixture $(6 \mathrm{ml})$ of conc. $\mathrm{HNO}_{3}$ $(17 \mathrm{M})$ and $\mathrm{HCl}(12 \mathrm{M})$ (Breder, 1982) was added and heated at $80^{\circ} \mathrm{C}$ until digestion was completed. The digests were allowed to cool and quantitatively transferred into $10 \mathrm{ml}$ volumetric flasks made up to mark using deionized water. The digestion mixture was transferred into $20 \mathrm{ml}$ polypropylene bottles ready for analysis. Reagent blanks were prepared in a similar manner for every batch.

The labile fraction was extracted from $0.5 \pm 0.05 \mathrm{~g}$ using 40 $\mathrm{ml}$ of $1 \mathrm{~N} \mathrm{HCl}$ at room temperature; samples were shaked for $2 \mathrm{~h}$, centrifuging at $5000 \mathrm{rpm}$ for $2 \mathrm{~min}$ and filtered in $50 \mathrm{ml}$ polypropylene bottles ready for analysis (Villares et al., 2003).

The resulting solutions were analyzed using an air-acetylene flame atomic absorption spectrophotometer (AAS) (Perkin Elmer, Model 2380) at optimum instrument operating conditions recommended by the manufacturer. The results were expressed in $\mathrm{mg}$ $\mathrm{kg}^{-1} \mathrm{dw}$ (UNEP/FAO/IAEA/IOC, 1984). The absorption wavelength and detection limits were as follows: $228.8 \mathrm{~nm}$ and $0.04 \mathrm{mg} \mathrm{kg}^{-1}$ for $\mathrm{Cd} ; 240.7 \mathrm{~nm}$ and $0.05 \mathrm{mg} \mathrm{kg}^{-1}$ for $\mathrm{Co} ; 357.9 \mathrm{~nm}$ and $0.06 \mathrm{mg} \mathrm{kg}$ for $\mathrm{Cr} ; 324.7 \mathrm{~nm}$ and $0.06 \mathrm{mg} \mathrm{kg}^{-1}$ for $\mathrm{Cu} ; 248.3 \mathrm{~nm}$ and $0.8 \mathrm{mg} \mathrm{kg}$ for Fe; $279.5 \mathrm{~nm}$ and $0.07 \mathrm{mg} \mathrm{kg}^{-1}$ for $\mathrm{Mn} ; 232.0 \mathrm{~nm}$ and $0.09 \mathrm{mg} \mathrm{kg}-$ for $\mathrm{Ni} ; 217.0 \mathrm{~nm}$ and $0.8 \mathrm{mg} \mathrm{kg}^{-1}$ for $\mathrm{Pb} ; 213.9 \mathrm{~nm}$ and $0.7 \mathrm{mg} \mathrm{kg}^{-1}$ for $\mathrm{Zn}$, respectively.

Reagents of analytical grade were utilized for the blanks and calibration curves. Precision was checked against standard reference material, provided by the National Research Council of Canada (MESS-2 marine sediment) and lied within the range of certified values with 91 97\% recovery for all metals studied. 
To prevent contamination, all used glass and plastic lab-ware were previously washed in dilute nitric acid and deionized water. RESULTS AND DISCUSSION

The concentrations of heavy metals ( $\mathrm{Cd}, \mathrm{Co}, \mathrm{Cr}, \mathrm{Cu}, \mathrm{Fe}, \mathrm{Mn}$, $\mathrm{Ni}, \mathrm{Pd}$ and $\mathrm{Zn}$ ) of total and labile fractions are shown in Table $\mathrm{I}$ and 2 , respectively. The average concentrations of heavy metals in total fraction can be arranged in the decreasing order $\mathrm{Fe}>\mathrm{Mn}>\mathrm{Cu}>\mathrm{Ni}>$ $\mathrm{Zn}>\mathrm{Cr}>\mathrm{Pb}>\mathrm{Co}>\mathrm{Cd}$ and the average concentrations of heavy metals in labile fraction in the order $\mathrm{Fe}>\mathrm{Mn}>\mathrm{Cu}>\mathrm{Ni}>\mathrm{Pb}>\mathrm{Zn}>$ $\mathrm{Co}>\mathrm{Cr}>\mathrm{Cd}$.

Iron ( $\mathrm{Fe}$ ) concentrations were ranged between 12755 to 45869 $\mathrm{mg} \mathrm{kg}{ }^{-1}$ in total fraction; and 2303 to 8997 for labile fraction, which recorded the new input metals. The ratio of the heavy metal concentrations in the labile fraction to the total concentrations of metals in the sediment, expressed as a percentage, is known as the percentage of extractability. This has been used as a theoretic estimate of the relative importance of metal of anthropogenic origin (Carral et al., 1994) and refers to the new input percentage (NIP) of heavy metals (Table 3). NIP for Fe fluctuated between 15.14 at site 2 to $32.45 \%$ at site 9 . The maximum concentration of $\mathrm{Fe}$ was recorded at site 9 (45870 mg kg $\mathrm{g}^{-1}$, which is facing Brimbal fresh water Canal. The maximum concentration of $\mathrm{Fe}$ intotal fraction was 1.5 times more the that recorded in sediments of Danube River $\left(29700 \mathrm{mg} \mathrm{kg}^{-1}\right.$ ) (Woitke et al., 2003) and 2 times of that recorded in sediment of NW Spain (22957 $\mathrm{mg} \mathrm{kg}^{-1}$ ) (Villares et al., 2003). On the other hand, the maximum concentration of $\mathrm{Fe}\left(8997 \mathrm{mg} \mathrm{kg}^{-1}\right)$ in the labile fraction was 2.7 times of that recorded in labile fraction in sediments of $\mathrm{NW}$ Spain (3362 $\mathrm{mg} \mathrm{kg}^{-1}$ ) (Villares et al., 2003).

Manganese $(\mathrm{Mn})$ concentrations fluctuated between 1311 to 4008 and 1144 to $3588 \mathrm{mg} \mathrm{kg}^{-1}$ for total and labile fractions, respectively. The NIP for $\mathrm{Mn}$ ranged between 74.11 and $90.95 \%$, which indicates that most $\mathrm{Mn}$ recorded was new input to the lake. The maximum concentrations of $\mathrm{Mn}$ recorded for total and labile fractions in this study were 8.5 and 55 times of that recorded in the total and labile fraction, respectively, in sediments of NW Spain (Villares et al. 2003). The average concentration of $\mathrm{Mn}\left(2069 \mathrm{mg} \mathrm{kg}^{-1}\right)$ in total fraction was 2.5 time of that of Danube river $\left(819 \mathrm{mg} \mathrm{kg}^{-1}\right.$ ) (Woitke et al., 2003).

Copper $(\mathrm{Cu})$, which is regarded as a serious pollutant of aquatic ecosystems, was the third higher in concentration during this 
study in both total and labile fractions. Cu concentrations fluctuated between 32.27 to $167.1 \mathrm{mg} \mathrm{kg}^{-1}$ for total fraction and 28.25 to 109.75 $\mathrm{mg} \mathrm{kg}^{-1}$ for labile fraction with NIP from 45.14 to $87.54 \%$. The highest NIP was recorded at site 5, which is located at the center of the lake (Fig. 1). However, only site 5 recorded a lower $\mathrm{Cu}$ concentration (32.27 $\mathrm{mg} \mathrm{kg}^{-1}$ ) than the Effect Range-Low value (ERL $=34 \mathrm{mg} \mathrm{kg}^{-1}$ ), while the other 10 studied sites showed higher concentration values than ERL but lower than the Effect RangeMedian value $\left(E R M=270 \mathrm{mg} \mathrm{kg}^{-1}\right)($ Table 1). The average concentration of $\mathrm{Cu}$ in this study was $113 \pm 43.7 \mathrm{mg} \mathrm{kg}^{-1}$ (for total fraction), which is 2 times that recorded for Danube river $(65.7 \pm 12.3$ $\mathrm{mg} \mathrm{kg}^{-1}$ ) (Woitke et al., 2003) and 10 times for NW Spain (10.87 \pm $15.79 \mathrm{mg} \mathrm{kg}^{-1}$ ) (Villares et al., 2003).

Nickel $(\mathrm{Ni})$ is one of the major elemental concentrations on the earth, constituting about $2 \%$ by weight (Nriagu, 1980). In this study, $\mathrm{Ni}$ concentrations ranged between 64.2 to $115.7 \mathrm{mg} \mathrm{kg}^{-1}$ for total fraction and 48 to $68 \mathrm{mg} \mathrm{kg}^{-1}$ for labile fraction with NIP between 58.8 to $90 \%$. All studied locations except site 11 recorded NIP over $66 \%$, which suggested a highly new input of $\mathrm{Ni}$ in the lake during the last few years. The average concentration of $\mathrm{Ni}$ in this study was $78.45 \pm 13.57 \mathrm{mg} \mathrm{kg}^{-1}$ (for total fraction), which is 1.6 times that recorded for Danube river $\left(49.6 \pm 6.1 \mathrm{mg} \mathrm{kg}^{-1}\right.$ ) (Woitke et al., 2003). However, $\mathrm{Ni}$ is present in significant concentrations in industrial and municipal discharges $\left(3.8 \times 10^{6} \mathrm{~kg} \mathrm{year}^{-1}\right)$, particularly in steel mill and electroplating wastes. Dissolved nickel levels in unpolluted fresh water usually range from 1 to $3 \mu \mathrm{g} \mathrm{l}^{-1}$, and input from mixed industrial urban sources may increase to $10-15 \mu \mathrm{g} \mathrm{I}^{-1}$ (Snodgrass, 1980). Nickel and its compounds caused a variety of cancer in rodents and are listed as possible causative agents for occupational or environmental cancer in man (Dunnick et al., 1995), but its toxicity toward aquatic biota is not well known.

Zinc $(\mathrm{Zn})$ concentration values recorded in this study ranged between 44.83 to $141.37 \mathrm{mg} \mathrm{kg}^{-1}$ with an average value $78.41 \pm 27.45$ $\mathrm{mg} \mathrm{kg}-1$ in the total fraction and 30.53 to $84.69 \mathrm{mg} \mathrm{kg}^{-1}$ with an average value $50.67 \pm 15.6 \mathrm{mg} \mathrm{kg}^{-1}$ in the labile fraction. NIP of $\mathrm{Zn}$ ranged between 45.19 to $86.57 \%$, indicating that over $60 \%$ of $\mathrm{Zn}$ concentration detected in Lake Burullus was a new input. However, the concentrations of $\mathrm{Zn}$ recorded for the eleven studied locations were not exceeding the ERL value $\left(150 \mathrm{mg} \mathrm{kg}^{-1}\right)$. The average 
concentration of $\mathrm{Zn}$ in total fraction was $40 \%$ of the average concentration recorded for Danube river $\left(187 \pm 25 \mathrm{mg} \mathrm{kg}^{-1}\right.$ ) (Woitke et al., 2003) and 2 times that recorded for NW Spain (41 $\pm 27.1 \mathrm{mg}$ $\mathrm{kg}^{-1}$ ). However, the average concentration of $\mathrm{Zn}$ in labile fraction was 4.2 times that for NW Spain (11.9 $\pm 16.4 \mathrm{mg} \mathrm{kg}^{-1}$ ) (Villares et al., 2003).

Chromium $(\mathrm{Cr})$ concentrations fluctuated between 50.81 to $81.98 \mathrm{mg} \mathrm{kg}^{-1}$ with average value $62.26 \pm 10 \mathrm{mg} \mathrm{kg}^{-1}$ in the total fraction and 15.09 to $48.15 \mathrm{mg} \mathrm{kg}^{-1}$ with average value $29.16 \pm 10.52$ $\mathrm{mg} \mathrm{kg}^{-1}$ in the labile fraction. NIP for $\mathrm{Cr}$ ranged between 25.17 to $66.67 \%$ with only five locations recording NIP over $50 \%$. The $\mathrm{Cr}$ concentrations in the total fraction were lower than the ERL value ( 81 $\left.\mathrm{mg} \mathrm{kg}{ }^{-1}\right)$ for all studied locations except site $11\left(81.98 \mathrm{mg} \mathrm{kg}^{-1}\right)$, which lies near to Brimbal fresh water Canal. However, the average concentration of $\mathrm{Cr}$ in total fraction was much closer to that reported in Danube river $\left(64 \pm 12.3 \mathrm{mg} \mathrm{kg}^{-1}\right)$ while it was 4.6 times that reported for NW Spain $\left(14.46 \pm 10.48 \mathrm{mg} \mathrm{kg}^{-1}\right)$.

The concentrations of lead $(\mathrm{Pb})$ in this study fluctuated from 46.18 to $80.35 \mathrm{mg} \mathrm{kg}^{-1}$ with average value $60.18 \pm 12.5 \mathrm{mg} \mathrm{kg}^{-1}$ in the total fraction and 31.70 to $69.85 \mathrm{mg} \mathrm{kg}^{-1}$ with average value 50.9 $\pm 12.07 \mathrm{mg} \mathrm{kg}^{-1}$ in the labile fraction. Pb exhibited NIP from 68.34 to $9126 \%$, indicating a highly new input of $\mathrm{Ph}$ to the Iake Total fraction showed $\mathrm{Pb}$ concentrations over the ERL value $\left(46.7 \mathrm{mg} \mathrm{kg}^{-1}\right.$ ) for all the studied locations except sites 6 and 8 (Table 1) but much lower than the ERM value $\left(218 \mathrm{mg} \mathrm{kg}^{-1}\right)$. However, total fraction showed average concentration of $\mathrm{Pb} \sim 1.3$ times that reported for both of Danube river $\left(46.3 \pm 6.8 \mathrm{mg} \mathrm{kg}^{-1}\right)$ and NW Spain ( $43.3 \pm 27.1 \mathrm{mg}$ $\mathrm{kg}^{-1}$ ), while it was 4.3 times that reported for labile fraction of $\mathrm{NW}$ Spain $\left(11.9 \pm 16.4 \mathrm{mg} \mathrm{kg}^{-1}\right)$.

The concentrations of cobalt (Co) fluctuated between 35.05 to $76.9 \mathrm{mg} \mathrm{kg}^{-1}$ with average value $44.9 \pm 11.65 \mathrm{mg} \mathrm{kg}^{-1}$ in the total fraction and 26.37 to $59.15 \mathrm{mg} \mathrm{kg}^{-1}$ with average value $35.41 \pm 8.97$ $\mathrm{mg} \mathrm{kg}^{-1}$ in the labile fraction. Co recorded NIP values between 65.79 and $91.57 \%$, which suggested a highly new input of Co to the Lake. The average concentration of $\mathrm{Co}$ in this study was 8.5 and 120 times the total and labile fractions, respectively, of Co average concentration reported for sediments in NW Spain.

Cadmium (Cd) concentrations ranged between 7.4 to 12.34 $\mathrm{mg} \mathrm{k}^{-1}$ with average concentration $9.59 \pm 1.46 \mathrm{mg} \mathrm{kg}^{-1}$ in the total fraction and 5.05 to $8.33 \mathrm{mg} \mathrm{kg}^{-1}$ with average value $6.84 \pm 1.03 \mathrm{mg}$ 
$\mathrm{kg}^{-1}$ in the labile fraction. Cd recorded NIP values between 54.71 and $93.15 \%$, which suggested a highly new input of $\mathrm{Cd}$ to the Lake. $\mathrm{Cd}$ is contained in some phosphate-based fertilizers. Such sources could constitute a major source of $\mathrm{Cd}$ that may reach humans. In addition, sewage sludge from wastewater treatment may contain significant quantities of $\mathrm{Cd}$. $\mathrm{Cd}$ is also a by-product of $\mathrm{Zn}$ smelting (Alloway, 1990). The application of sewage sludge and tailings from mines into landfills is another potential source of $\mathrm{Cd}$ contamination. In this study, total fraction exhibited Cd concentrations over the ERL value (1.2 $\mathrm{mg} \mathrm{kg}^{-1}$ ) for all studied locations and over the ERM value $(9.6$ $\mathrm{mg} \mathrm{kg}^{-1}$ ) for sites $3,5,7$ and 10 (Table 1). The average concentration of $\mathrm{Cd}$ in this study was 8 times the total fractions reported for sediment of Danube river $\left(1.2 \pm 0.4 \mathrm{mg} \mathrm{kg}^{-1}\right)$.

\section{Metal pollution index}

The overall metal contents of total and labile fractions at the sites investigated in this study were compared, using the metal pollution index (MPI) calculated according to Usero et al. (1996 and 1997) with the formula:

$\mathrm{MPI}=(\mathrm{Cd} \times \mathrm{Co} \times \mathrm{Cr} \times \mathrm{Cu} \times \mathrm{Fe} \times \mathrm{Mn} \times \mathrm{Ni} \times \mathrm{Pb} \times \mathrm{Zn})^{1 / 9}$

MPI ratios ranged between 115.74 to 252.57 with average 162.51 for total fraction and 72.36 to 121.09 with average 92.51 for labile fraction (Tables 1 and 2). MPI exhibited high values due to the higher concentrations of all studied metals especially $\mathrm{Fe}, \mathrm{Mn}, \mathrm{Cu}$ and $\mathrm{Zn}$. Therefore, MPI suggested highly polluted sediments of Lake Burullus.

\section{Statistical analysis}

Spearman (Non-Paramatic) rank order correlations for studied heavy metals concentrations in total and labile fractions are summarized in Tables 4 and 5, respectively. Total fractions exhibited poor positive correlations for most of the metals, while for $\mathrm{Cd}, \mathrm{Co}, \mathrm{Cr}$ and $\mathrm{Fe}$ concentrations were significant $(\mathrm{p}<0.05)$. The positive correlations $(P<0.008)$ were recorded between $\mathrm{Mn}$ vs $\mathrm{Fe}(r=0.75)$; $\mathrm{Mn}$ vs $\mathrm{Cr}(\mathrm{r}=0.88)$; Co vs $\mathrm{Cr}(\mathrm{r}=0.80)$ and $\mathrm{Co}$ vs $\mathrm{Ni}(\mathrm{r}=0.76)$. Negative correlations were recorded between $\mathrm{Cd}$ vs $\mathrm{Cr}(\mathrm{r}=-0.68)$ and $\mathrm{Cd}$ vs $\mathrm{Fe}(\mathrm{r}=-0.58)$ (Table 4). Labile fractions also exhibited poor positive correlations for most of the metals, but for $\mathrm{Cd}$, Co and $\mathrm{Cr}$ concentrations were significant $(\mathrm{p}<0.05)$. Negative correlation was recorded between $\mathrm{Cd}$ ys $\mathrm{Cr}(\mathrm{r}=-0.78)$ while positive correlation 
were recorded between $\mathrm{Cd}$ vs Ni $(\mathrm{r}=0.82)$; Co vs $\mathrm{Fe}(\mathrm{r}=0.59)$; Co vs $\mathrm{Pb}(\mathrm{r}=0.59)$ and $\mathrm{Cr}$ vs $\mathrm{Mn}(\mathrm{r}=0.63)$ (Table 5).

Multivariate statistics particularly factor analysis had enabled grouping of variables (heavy metals in this case) into a number of factors that exhibit a common behavior. In this way, the number of variables under investigation was reduced and interelement associations might be assessed in detail. Davis (1986) described effectively the method's principles, whilst numerous investigations benefited from its use (Nath et al., 1989; Hodkinson and Cronan, 1991). R-mode factor analysis with varimax rotation was applied to the heavy metal concentrations in sediment and four-factor model explaining $90.23 \%$ and $87.88 \%$ of the total variance that were adopted for total and labile fractions, respectively (Table 6).

Factor 1 for total fraction accounts for $36.25 \%$ of the total data variance and shows a bipolar character. High positive loadings concern $\mathrm{Cr}, \mathrm{Fe}, \mathrm{Mn}$ and partly $\mathrm{Co}$. These elements are known to be associated to hydrothermal processes, thus will be considered "hydrothermal factors". Hydrothermal fluids may have been responsible for the accumulation of metal oxides. In this four factors model, iron and Co are also represented partly in factors 2, 3 and 4; and manganese and chromium are presented partly in factor 3 . These being controlled primarily by diagenetic re-mobilisation from sapropel layers. The allochthonous detrital phase is opposed to the autochthonous biogenous phase, which is represented by $\mathrm{Cd}$ that showed negative loadings.

Factor 2 for total fraction accounts for $20.96 \%$ of the data variance and showed high loadings for three metals namely $\mathrm{Pb}, \mathrm{Zn}$ and partly $\mathrm{Co}$ while $\mathrm{Fe}$. $\mathrm{Co}$ and $\mathrm{Fe}$ are associated to hydrothermal processes, thus will be partly named "hydrothermal factors". The absence of $\mathrm{Mn}$ participation in this factor is striking, while $\mathrm{Zn}$ is associated to sapropelic factor. $\mathrm{Pb}$ is incorporated into terrigenous alumino-silicates and, therefore, $\mathrm{Pb}$ can be associated to "terrigenous alumino-silicate factor", further corresponding to the "mud lithological unit".

Factore 3 accounted for $17.57 \%$ of the total data variance (Table 6) and showed high loadings for $\mathrm{Ni}$ and partly $\mathrm{Co}, \mathrm{Cr}$ and $\mathrm{Mn}$. These elements are associated to hydrothermal processes, thus will be named "hydrothermal factor".

Factor 4 accounted for $15.45 \%$ of the total variance and showed high loadings for $\mathrm{Cu}$ and partly $\mathrm{Fe}$ and $\mathrm{Zn}$. $\mathrm{Cu}$ and $\mathrm{Fe}$ are associated to hydrothermal processes. 


\section{ASSESSMENT OF HEAVY METAL POLLUTION IN SURFACE MUDDY SEDIMENTS OF LAKE BURULLUS,}

Factor 1 for labile fraction accounts for $26.77 \%$ of the total data variance and showed a bipolar character. High positive loadings concerned $\mathrm{Cd}$ and $\mathrm{Ni}$ and partly $\mathrm{Co}$. These elements are associated to hydrothermal processes, thus will be named "hydrothermal factor". $\mathrm{Cr}$ is represented by partly negative loadings.

Factor 2 for labile fraction accounts for $23.24 \%$ of the total data variance and showed a high positive loadings concerning $\mathrm{Co}, \mathrm{Fe}$ and $\mathrm{Pb}$. Factor 3 showed high positive loadings concerning $\mathrm{Cr}, \mathrm{Mn}$ and partly $\mathrm{Co}_{0}$, which are associated to hydrothermal processes, and could be named "hydrothermal factor". Factor 4 showed a bipolar character and high positive loadings concerning $\mathrm{Cu}$ and $\mathrm{Zn}$.

\section{Human health risk due to exposure to contaminated sediments}

The ingestion of sediment (Table 7), dermal contact with contaminated sediment (Table 8) and lifetime daily exposure (Table 9) were calculated for the studied locations of Lake Burullus for assessment of the human health risk, depending on the calculation made by Albering et al. (1999).

Ingestion of contaminated sediment (ICS) ( $\mathrm{mg} \mathrm{kg}^{-1}$ day $^{-1}$ )

$=(\mathrm{CS} \times \mathrm{IRS} \times \mathrm{EF} \times \mathrm{AF}) \div \mathrm{BW}$

Dermal contact with contaminated sediment (DCCS) $\left(\mathrm{mg} \mathrm{kg}^{-1} \mathrm{day}^{-1}\right)$ $=(\mathrm{CS} \times \mathrm{SAS} \times \mathrm{AD} \times \mathrm{ASS} \times \mathrm{Mf} \times \mathrm{EDS} \times \mathrm{EF} \times \mathrm{AF}) \div \mathrm{BW}$

Calculated lifetime daily exposure (CLTDE) $\left(\mathrm{mg} \mathrm{kg}^{-1}\right.$ day $\left.^{-1}\right)$

$=\left[\left(6 \times \mathrm{TEL}_{\text {child }}\right) \div 70\right]+\left[\left(64 \times \mathrm{TEL}_{\text {adult }}\right) \div 7\right]$

Hazard index $=$ CLTDE $\div$ tolerable daily intake $(T D)$

Where $\mathrm{CS}=$ concentration of the heavy metal contaminant in sediment $\left(\mathrm{mg} \mathrm{kg}^{-1}\right)$; IRS = ingestion rate of contaminated sediment $(0.001$ and $0.00035 \mathrm{~kg}$ dry weight/day for child and adult, respectively); $\mathrm{EF}=$ exposure frequency ( 30 for both child and adult); $\mathrm{AF}=$ absorption factor ( 1 for both child and adult) and $\mathrm{BW}=\mathrm{Body}$ weight (15 and $70 \mathrm{~kg}$ for child and adult, respectively); SAS = Dermal surface area for sediment exposure $\left(0.17\right.$ and $0.28 \mathrm{~m}^{2}$ for child and adult, respectively); $\mathrm{AD}=$ Dermal adherence rate for sediment $\left(0.51\right.$ and $3.75 \mathrm{mg} \mathrm{cm}^{-2}$ for child and adult, respectively); ASS $=$ Dermal absorption rate $\left(0.01\right.$ and 0.005 liter $\mathrm{hr}^{-1}$ for child and adult, respectively); $M F=$ Matrix factor $(0.15$ the for both child and adult); EDS $=$ Exposure duration to sediment $\left(8 \mathrm{hr} \mathrm{day}^{-1}\right.$ for both child and adult); $E F=$ Exposure frequency $\left(30\right.$ days year $^{-1}$ for both child and adult); TEL = total exposure levels; TDIs = tolerable daily intakes for heavy metals (Bockting et al., 1996). 
The concentrations of heavy metals recorded for sediments of Lake Burullus were high for all studied metals, which gave the ingestion of sediments (IS) for $\mathrm{Fe}$ and $\mathrm{Mn}$ in very high values (Table 7). $\mathrm{Fe}$ contamination in sediment showed IS between 25.51 to 91.74 and 1.91 to $6.88 \mathrm{mg} \mathrm{kg}^{-1}$ day $^{-1}$ for child and adult, respectively. $\mathrm{Mn}$ contamination in sediment showed IS between 2.62 to 8.01 and 0.20 to $0.60 \mathrm{mg} \mathrm{kg}^{-1} \mathrm{day}^{-1}$ for child and adult, respectively. The other metals exhibited high values but less than $1 \mathrm{mg} \mathrm{kg}^{-1}$ day $^{-1}$ for both child and adult. Also, dermal contact with contaminated sediment (DCCS) exhibited high values for $\mathrm{Fe}$ and $\mathrm{Mn}$ (Table 8). DCCS for Fe ranged from 26.54 to 95.45 and 34.44 to $123.85 \mathrm{mg} \mathrm{kg}^{-1} \mathrm{day}^{-1}$ for child and adult, respectively. Mn showed DCCS values from 2.73 to 7.52 and 3.54 to $9.75 \mathrm{mg} \mathrm{kg}^{-1}$ day $^{-1}$ for child and adult, respectively. The other heavy metals in sediments of Lake Burullus recorded high values of DCCS but still less than $1 \mathrm{mg} \mathrm{kg}^{-1}$ day $^{-1}$. These high values led to high-calculated lifetime daily exposure (CLTDE) values, and therefore gave high hazard index values for all the studied sediments (Table 9). The results of these calculations indicate that sediment contamination by $\mathrm{Pb}, \mathrm{Cu}, \mathrm{Mn}, \mathrm{Cd}$ and $\mathrm{Zn}$ in Lake Burullus may present a health hazard if the risks are calculated based on the standard exposure model. Background exposures to $\mathrm{Cd}, \mathrm{Cu}, \mathrm{Pd}$ and $\mathrm{Zn}$ have been estimated to be approximately $0.26,21$, 0.46 , and $190 \mu \mathrm{g} \mathrm{kg}^{-1} \mathrm{day}^{-1}$, respectively (Albering et al., 1999). The hazard index coming from contaminated sediment showed an existence of risk from exposure to Lake Burullus. However, studying the contaminated fish and water are necessary to reveal the exact hazard index for the Lake.

\section{CONCLUSION}

This study showed that heavy metal concentrations in the sediments of Lake Burullus were higher than the ERL but lower than the ERM values for all the studied metals at most of the examined studied locations. The calculations of risk assessment showed a possible health risk due to exposure to the contaminated sediment for long time.

\section{REFERENCES}

Albering, H. J. ; Rila, J. - P. ; Moonen, E. J. C. ; Hoogeweff, J. A. and Kleinjans, J. C. S. (1999). Human health risk assessment in relation to environmental pollution of two artificial freshwater lakes in the Netherlands. Environ. Health Perspective, 107: 27-35. 
Alloway, B. J. (1990). Cadmium. In Alloway B. J. ; editor. Heavy metals in soils. New York : Halsted. 100-24pp.

Breder, R. (1982). Optimization studies for reliable trace metal analysis in sediments by atomic absorption spectrometric methods. Fresenius Z. Anal. Chem., 313: 395-402.

Bockting, G. J. M. ; Koolenbrander, J. G. M. and Swartjes, F. A. (1996). SEDISOIL. Estimation of human exposure to sediments [in Dutch]. Rpt no 715810011. Bilthoven, the Netherlands: National Institute of Public Health and the Environment.

Carral, E. ; Villares, R. ; Puente, X. and Carballeira, A. (1994). Characterization of sediment metal pollution in Galician Estuaries (NW Spain), in proceedings of the $6^{\text {th }}$ International Conference of Environmental Contamination, Delphi, Greece, October, 1994:281-283.

Davis, J. C. (1986). Statistics and data analysis in geology. J. Wiley \& Sons, New-York, 646pp.

Dunnick, J. K. ; Elwell, M. R. ; Radowsky, A. E. ; Benson, J. M. ; Hahn, F. F. ; Bart, E. B. and Hobbs, C. H. (1995). Comparative carcinogenic effects of nickel subsulfide, nickel oxide, or nickel hexahydrate chronic exposures in the lung. Cancer Research, 55: 5251-5256.

Frstner, U. and Wittman, G. T. W. (1983). Metal pollution in the aquatic environment. Berlin: Springer-Verlag.

Hodkinson, R. A. and Cronan, D. S. (1991). Geochemistry of recent hydrothermal sediments in relation to tectonic environment in the Lau Basin, southwest Pacific. Mar. Geol., 98: 353366. 
Lacerda, L. D. ; Fernandez, M. A. ; Calazans, C. F. and Tanizaki, K. F. (1992). Bioavailability of heavy metals in sediments of two coastal lagoons in Rio de Janeiro, Brazil, Hydrobiologia, 228: $65-70$.

Nath, B. N. ; Rao, V. P. and Becker, K. P. (1989). Geochemical evidence of terrigenous influence in deep-sea sediments up to 8 deg. $S$ in the central Indian basin. Mar. Geol, 87: 301313.

Nriagu, J. O. (1980). Global cycle and properties of nickel. In: Nriagu, J. O. (Ed.), Nickel in the Environment. Wiley, New York, pp. 1-26.

Puente, X. ; Villares, R. ; Carral, E. and Carballeira, A. (1996). Nacreous shell of Mytilus galloprovincialis as a biomonitor of heavy metal pollution in Galiza (NW Spain) Sci. Total Environ, 183: 205-211.

Schropp, S. J. ; Windom, H. L. (1988). A guide to the interpretation of metal concentrations in estuarine sediments, in Schropp, S. J.; Windom, H. L. (eds), Savannah, Georgia, 53 pp.

Snodgrass, W. J. (1980). Distribution and behavior of nickel in the aquatic environment. In: Nriagu, J. O. (Ed.), Nickel in the Environment. Wiley, New York, pp. 203-274.

UNEP/FAO/IAEA/IOC (1984). Sampling of selected marine organisms and sample preparation for trace metal analysis: Reference method for marine pollution studies No. 7, Rev. 2: $19 \mathrm{pp}$.

Usero, J. ; Gonzales-Regalado, E. and Gracia, 1. (1996). Trace metals in bivalve molluses Chamelea gallina from the Atlantic Coast of southern Spain. Mar. Pollut. Bull, 32: 305-310.

Usero, J. ; Gonzales-Regalado, E. and Gracia, I. (1997). Trace metals in bivalve molluscs Ruditapes decussatus and Ruditapes philippinarum from the Atlantic Coast of southern Spain Environ. Int., 23: 291-298. 
Villares, R. ; Puente, X. and Carballeira, A. (2003). Heavy metals in sandy sediments of the Rias Baixas (NW Spain) Environ. Mon. Assess. 83: 129-144.

Woitke, P. ; Wellmitz, J. ; Helm, D. ; Kube, P. ; Lepom, P. and Litheraty, P. (2003). Analysis and assessment of heavy metal pollution in suspended solids and sctiments of the river Danube. Chemosphere, 51: 633-642. 


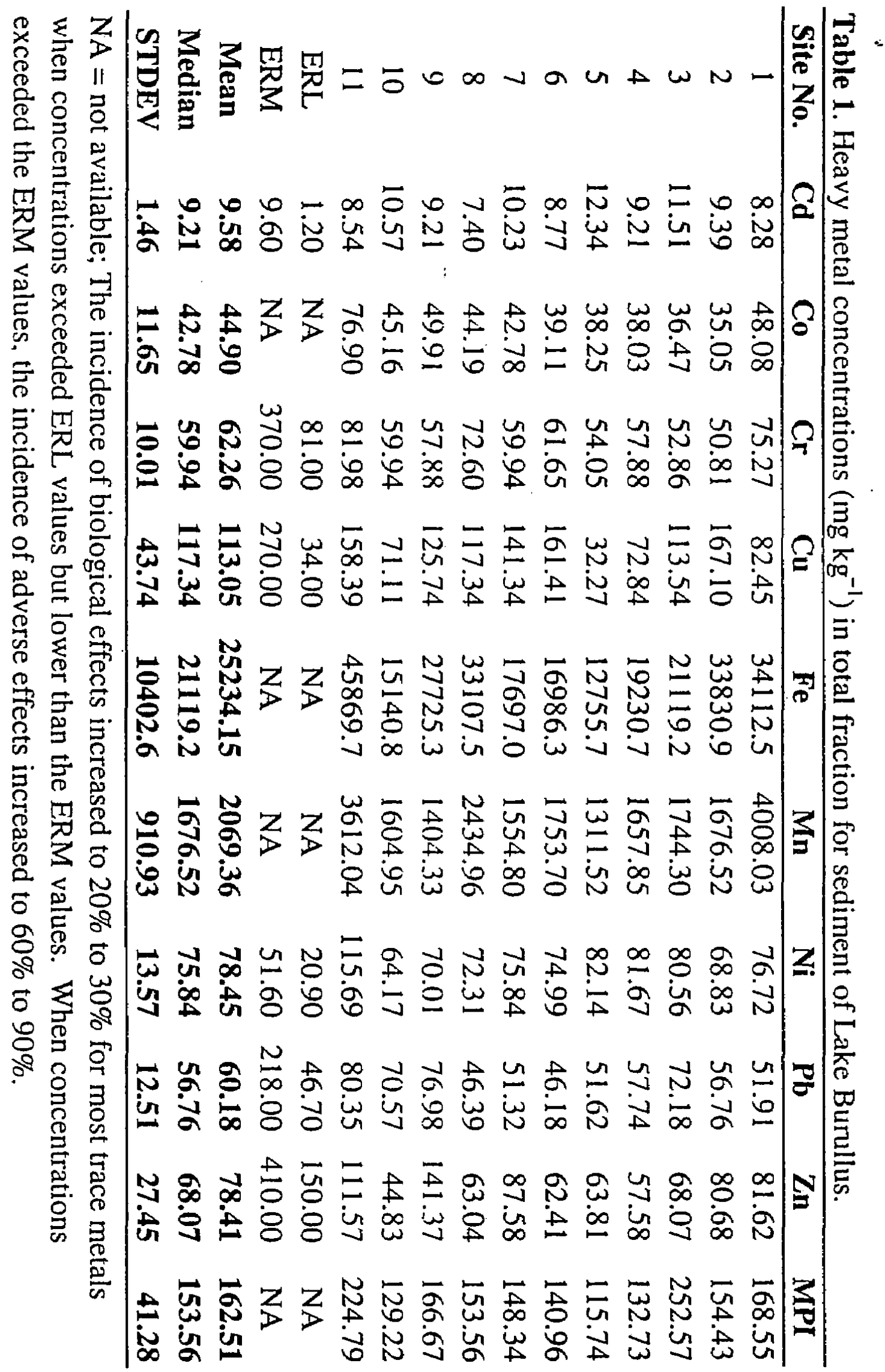




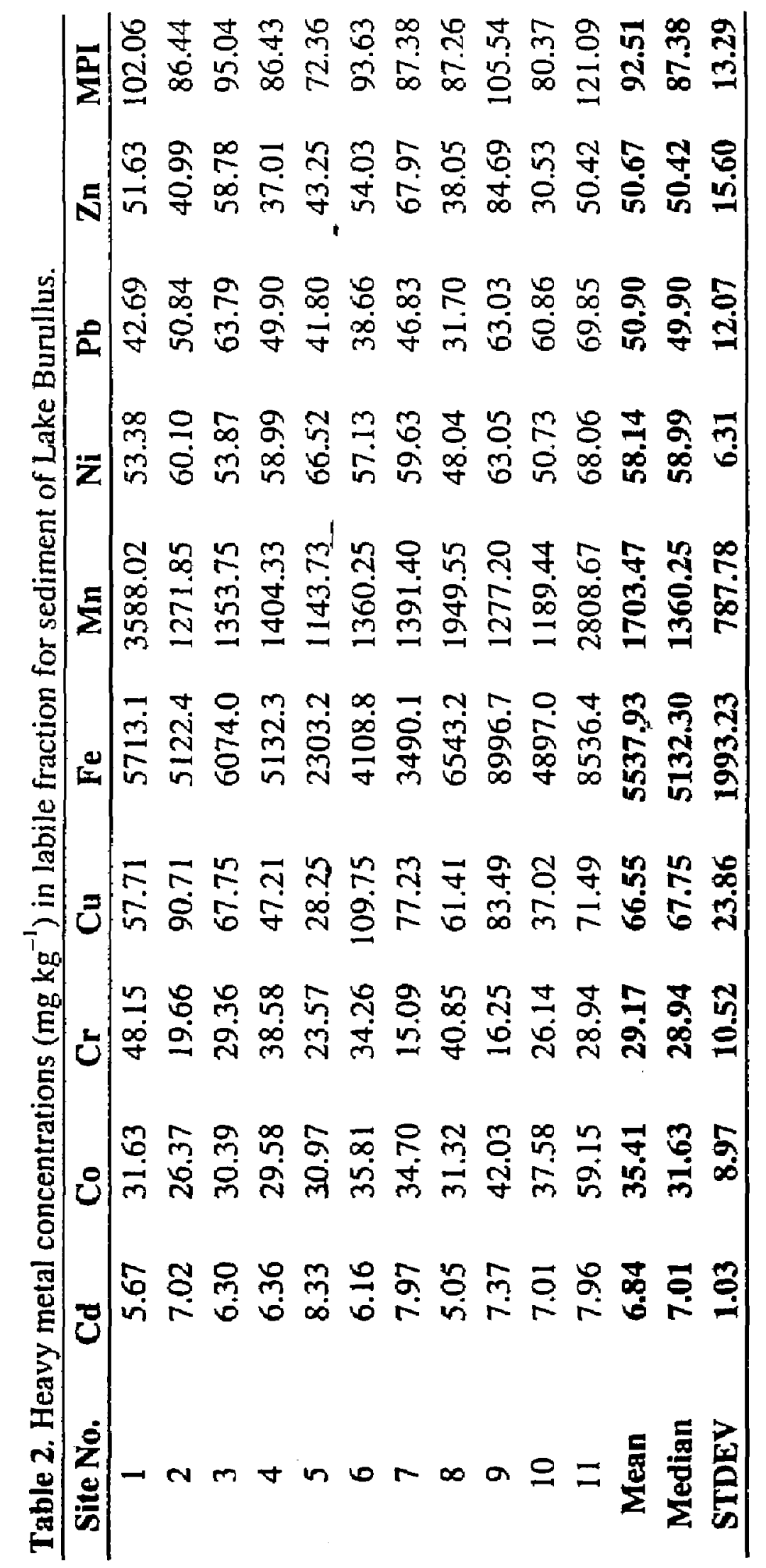




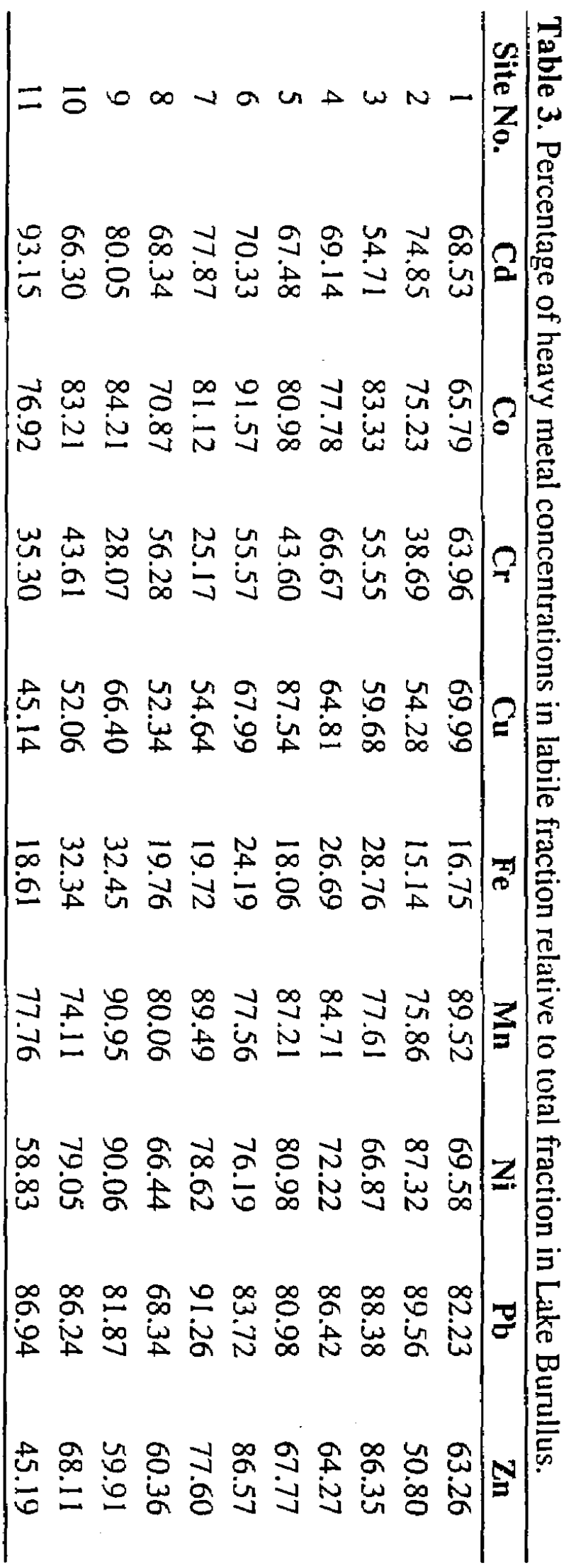




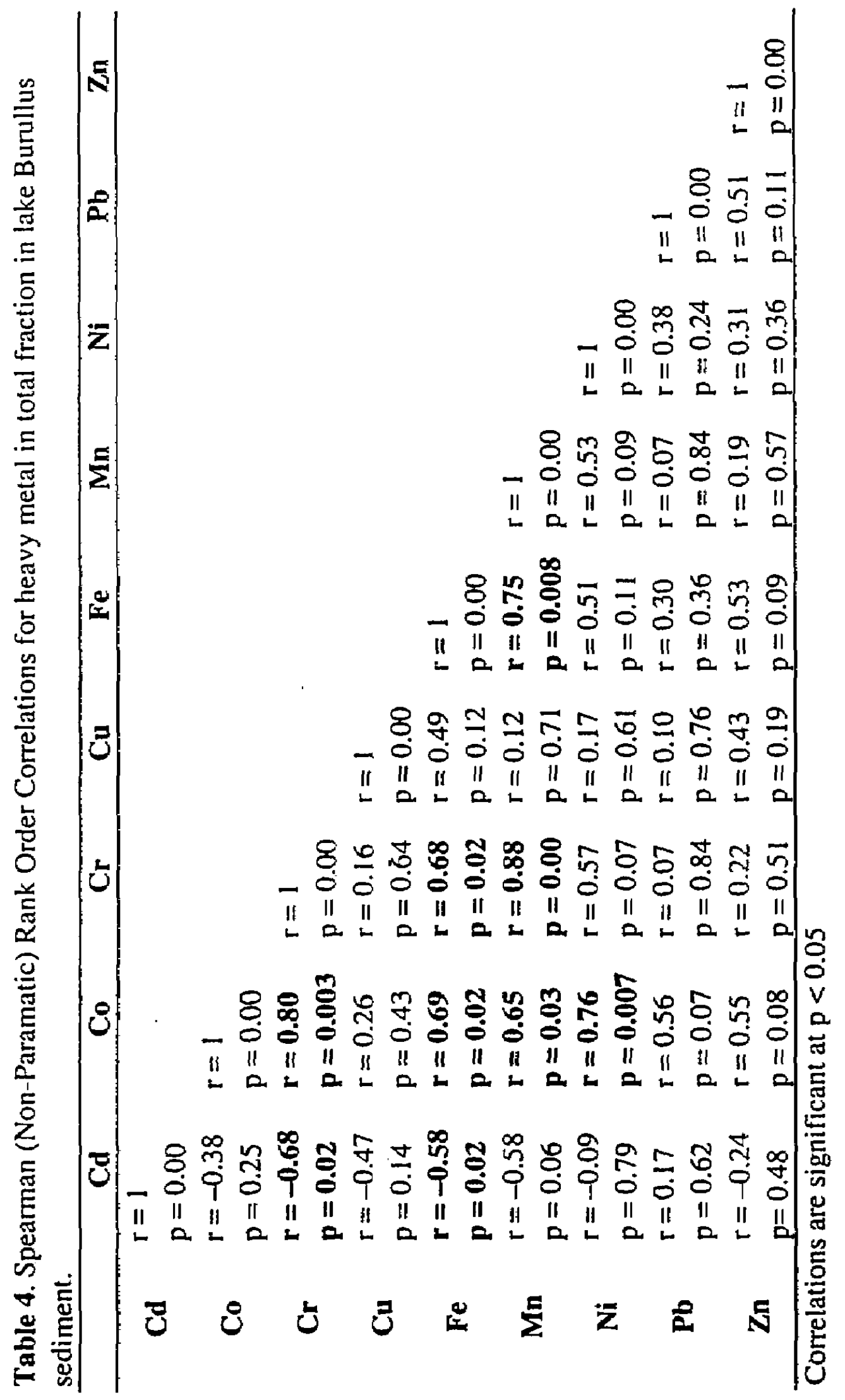




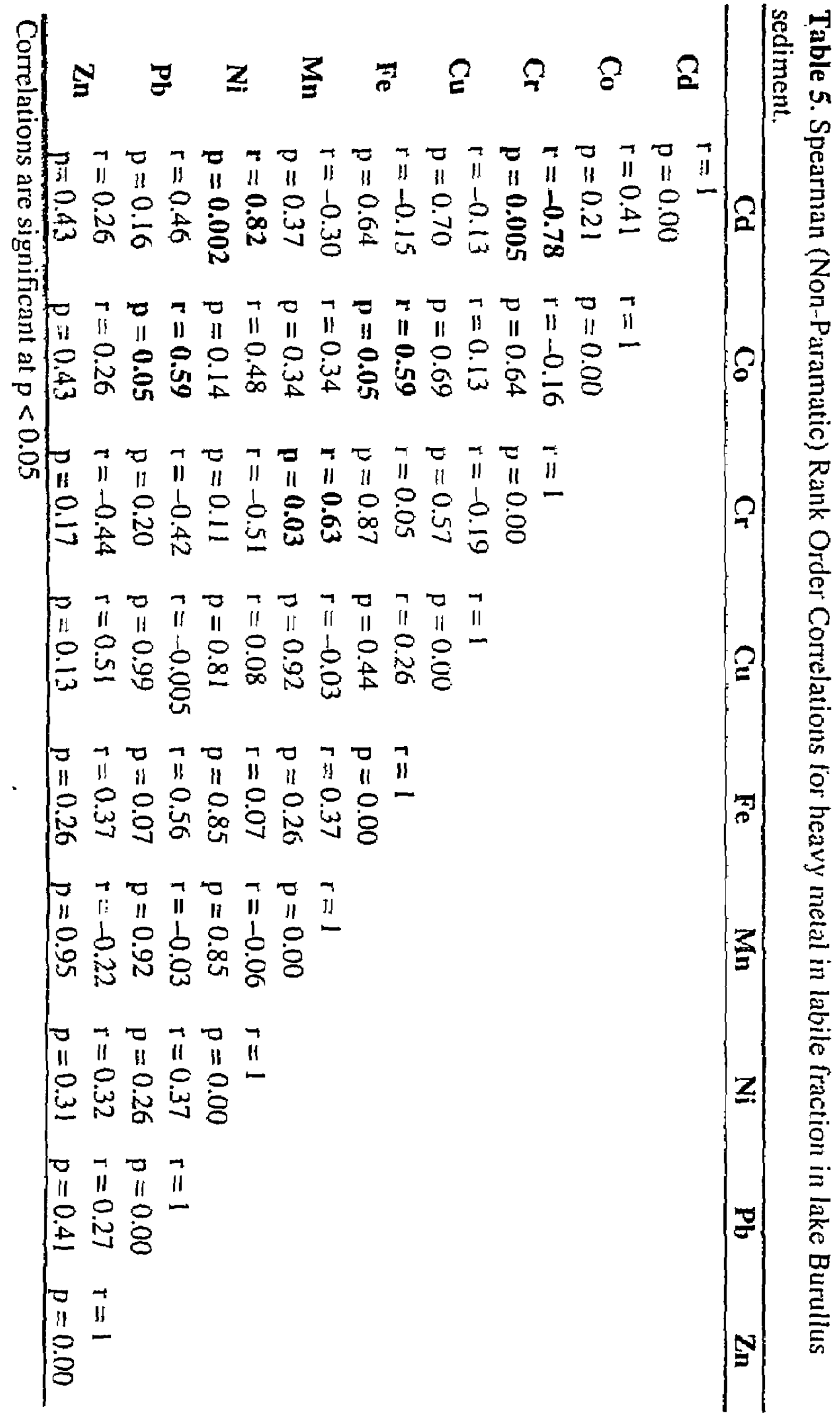




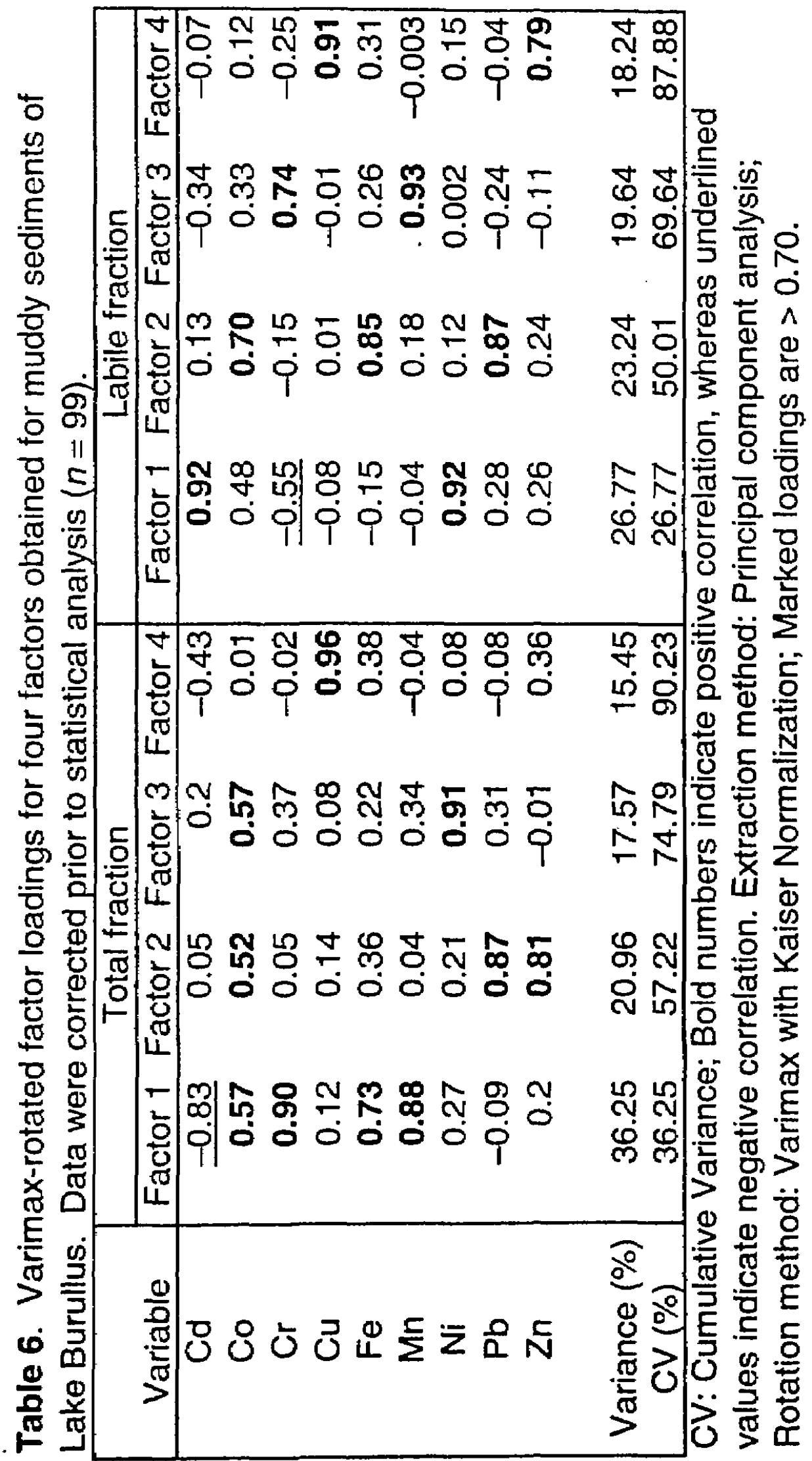




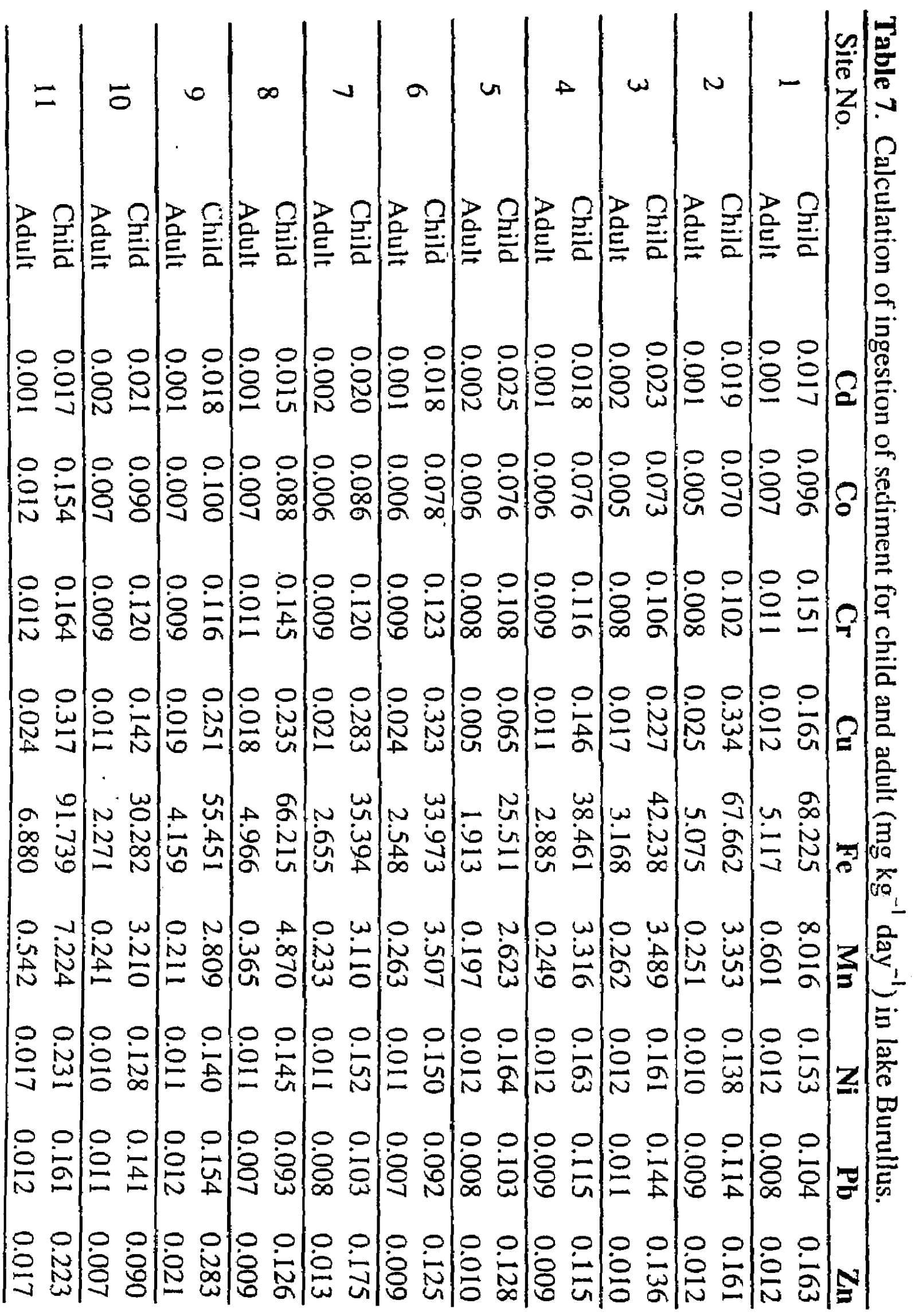




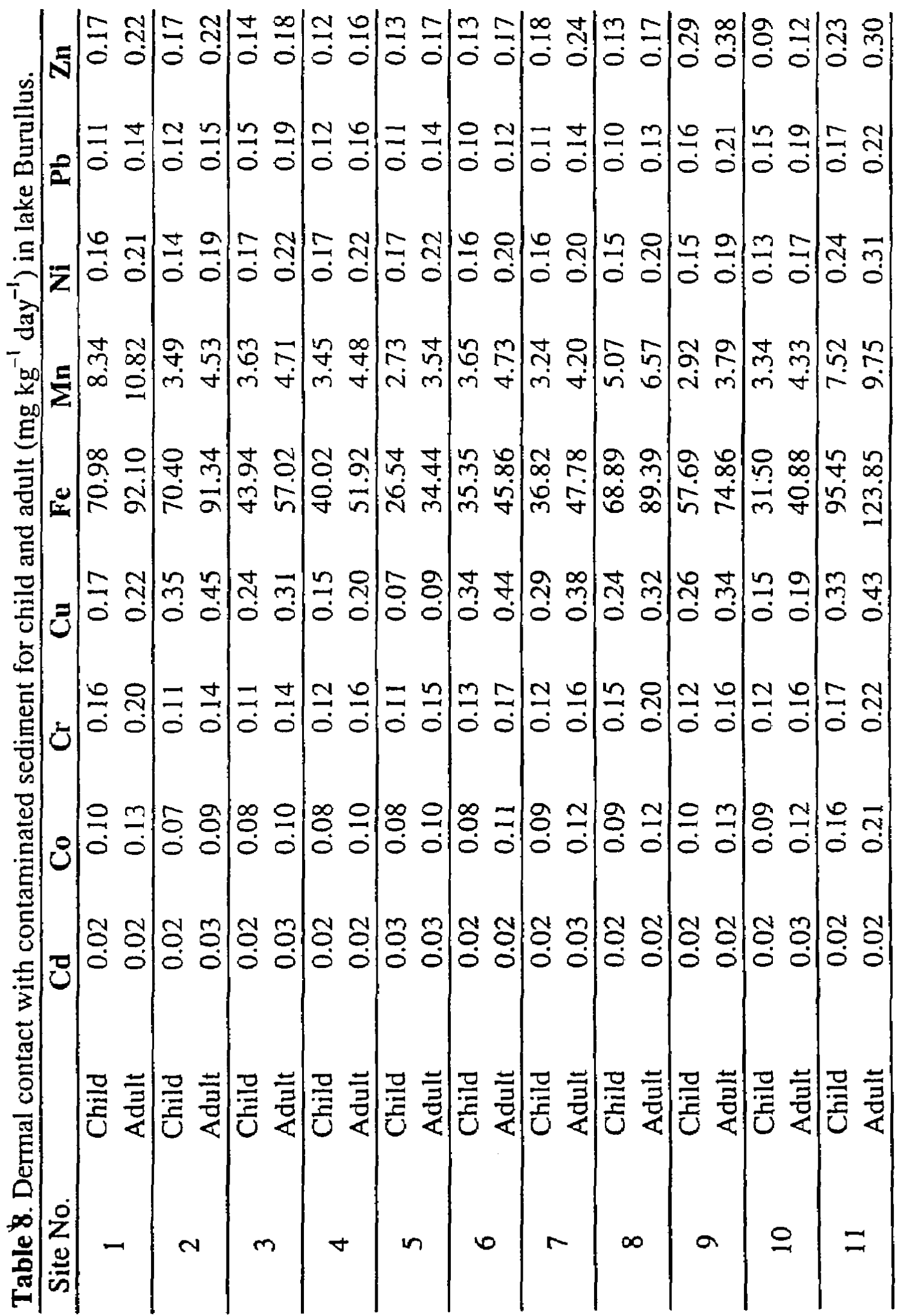




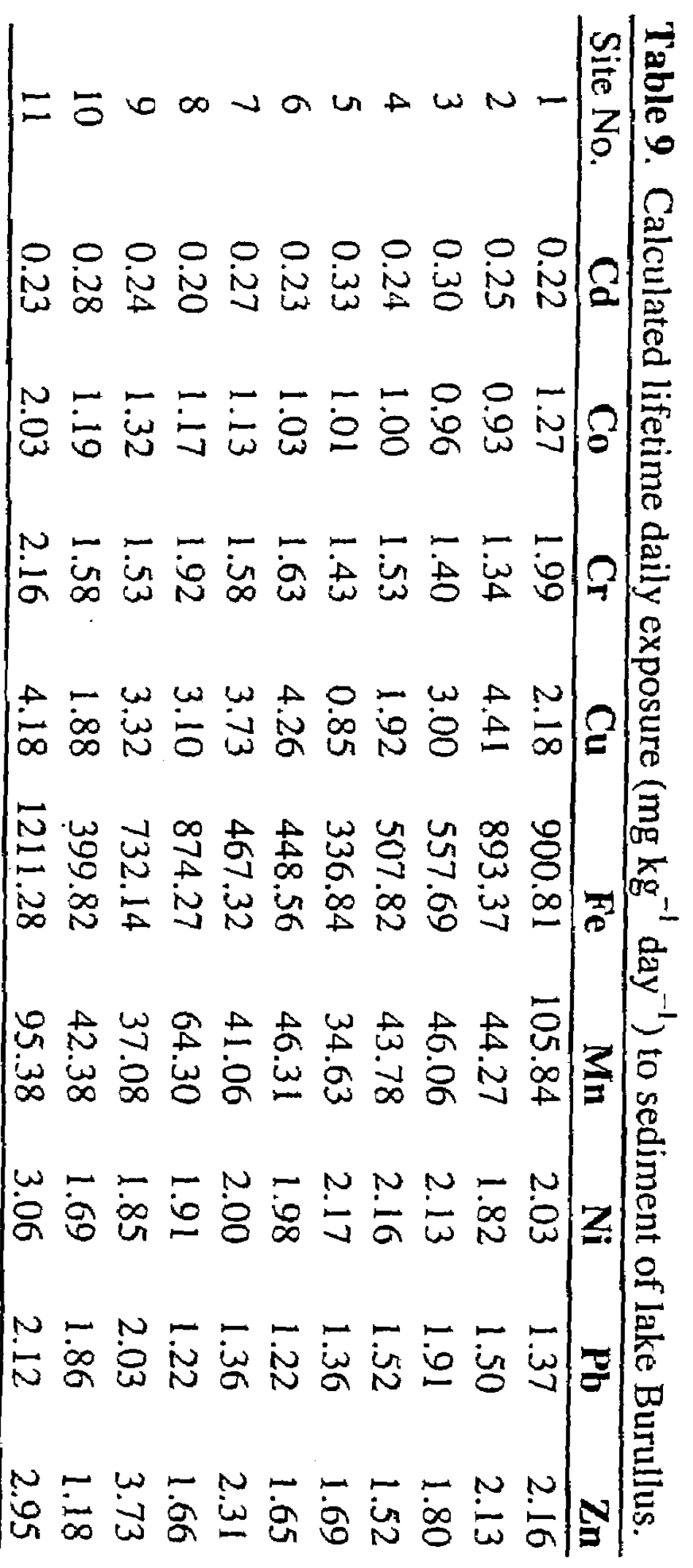




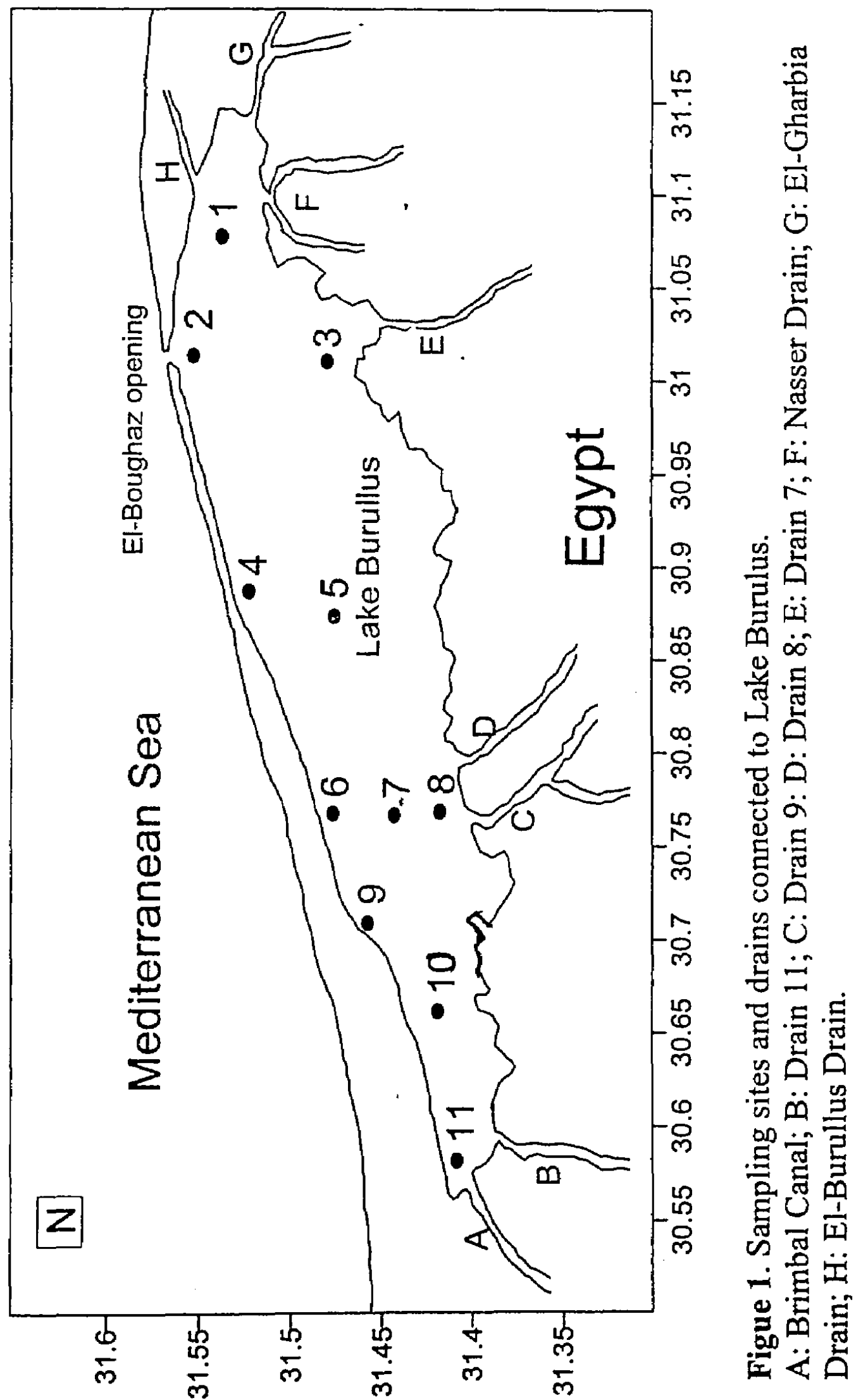

